\title{
Prothrombotic effects of tumor necrosis factor alpha in vivo are amplified by the absence of TNF-alpha receptor subtype 1 and require TNF-alpha receptor subtype 2
}

Joachim Pircher ${ }^{1,2^{*}+}$, Monika Merkle $^{1 \dagger}$, Markus Wörnle $^{1 \dagger}$, Andrea Ribeiro ${ }^{1}$, Thomas Czermak ${ }^{2}, Y_{\text {vonn Stampnik }}^{2}$, Hanna Mannell ${ }^{2}$, Markus Niemeyer ${ }^{3}$, Volker Vielhauer ${ }^{1}$ and Florian Krötz ${ }^{4}$

\begin{abstract}
Introduction: Elevated serum levels of the proinflammatory cytokine tumor necrosis factor alpha (TNF $\alpha$ ) correlate with an increased risk for atherothrombotic events and TNF $\alpha$ is known to induce prothrombotic molecules in endothelial cells. Based on the preexisting evidence for the impact of TNF $\alpha$ in the pathogenesis of autoimmune disorders and their known association with an acquired hypercoagulability, we investigated the effects of TNF $\alpha$ and the role of the TNF receptor subtypes TNFR1 and TNFR2 for arteriolar thrombosis in vivo.

Methods: Arteriolar thrombosis and platelet-rolling in vivo were investigated in wildtype, TNFR1-/-, TNFR2-/- and TNFR1-/R2-/- C57BL/6 mice using intravital microscopy in the dorsal skinfold chamber microcirculation model. In vitro, expression of prothrombotic molecules was assessed in human endothelial cells by real-time PCR and flow cytometry.
\end{abstract}

Results: In wildtype mice, stimulation with TNF $\alpha$ significantly accelerated thrombotic vessel occlusion in vivo upon ferric chloride injury. Arteriolar thrombosis was much more pronounced in TNFR1-/- animals, where TNF $\alpha$ additionally led to increased platelet-endothelium-interaction. TNF $\alpha$ dependent prothrombotic effects were not observed in TNFR2-/- and TNFR1-/R2- mice. In vitro, stimulation of human platelet rich plasma with TNF $\alpha$ did not influence aggregation properties. In human endothelial cells, TNF $\alpha$ induced superoxide production, p-selectin, tissue factor and PAI-1, and suppressed thrombomodulin, resulting in an accelerated endothelial dependent blood clotting in vitro. Additionally, TNF $\alpha$ caused the release of soluble mediators by endothelial cells which induced prothrombotic and suppressed anticoagulant genes comparable to direct TNF $\alpha$ effects.

Conclusions: TNF $\alpha$ accelerates thrombus formation in an in vivo model of arteriolar thrombosis. Its prothrombotic effects in vivo require TNFR2 and are partly compensated by TNFR1. In vitro studies indicate endothelial mechanisms to be responsible for prothrombotic TNF $\alpha$ effects. Our results support a more selective therapeutic approach in anticytokine therapy favouring TNFR2 specific antagonists.

\section{Introduction}

Tumor necrosis factor alpha (TNF $\alpha)$ is known to exert pleiotropic effects on the host defense which fundamentally differ depending on an acute or chronic release, the occurrence of a disequilibrium between pro- and anti-

\footnotetext{
* Correspondence: joachim.pircher@gmail.com

† Contributed equally

${ }^{1}$ Medizinische Klinik und Poliklinik IV, Innenstadt, Ludwig Maximilians University München, Ziemssenstr. 1, 80336 Munich, Germany Full list of author information is available at the end of the article
}

inflammatory mediators, and the concomitant regulation of other cytokines sharing certain biological properties. Trimeric TNF $\alpha$ acts by binding to one of the TNF $\alpha$ receptors (TNFRs): TNFR1 or TNFR2 [1,2]. Whereas TNFR1 is widely expressed, expression of TNFR2 is found mainly on immune and endothelial cells $[3,4]$. The receptors have different affinity for the soluble and the membrane-bound forms of TNF $\alpha$ (transmembrane TNF $\alpha$, or tmTNF $\alpha$ ); TNFR1 binds the two forms equally 
well, whereas TNFR2 has a higher affinity for tmTNFa. Both receptor subtypes are associated with the activation of nuclear factor-kappa-B (NF- $\kappa \mathrm{B})$. However, the signaling pathways are complex and partly crosslinked, and TNFa is able to induce cell death as well as proliferation, differentiation, and migration [5].

The impact of TNF $\alpha$ in the pathogenesis of autoimmune disorders such as systemic lupus erythematosus and rheumatoid arthritis (RA) has been widely accepted [6]. TNF $\alpha$ is known to mediate synovial cell proliferation and bone resorption in RA [7] as well as activation of endothelial cells and fibroblast chemotaxis in systemic sclerosis [8]. In patients with systemic lupus erythematosus, high serum levels of TNF $\alpha$ correlating with disease activity have been described, and its role in the development of lupus nephritis is accepted [9]. Additionally, patients affected by RA are at increased risk for cardiovascular morbidity and atherothrombotic events not ascribable to traditional risk factors [10-12]. Not only is atherosclerosis considered to be an inflammatory process with increased serum levels of TNF $\alpha$ present in patients with atherothrombotic diseases [13,14], but TNF $\alpha$ has been associated directly to endothelial dysfunction by mediating NF- $\kappa \mathrm{B}$ translocation, increasing production of reactive oxygen species, and affecting endothelial nitric oxide synthase expression [15-17]. In addition, systemic inflammation implicates prothrombotic conditions by upregulation of procoagulant factors, downregulation of natural anticoagulants, and inhibition of fibrinolysis. More specifically, TNF $\alpha$ induces the expression of tissue factor and suppresses thrombomodulin as well as the endothelial cell protein C receptor $[18,19]$. Hence, an acquired hypercoagulability is frequently associated with autoimmune disorders. Finally, platelets represent a further important link between inflammation, atherogenesis, and thrombosis $[20,21]$.

An effective blockade of TNF $\alpha$-dependent cytokine cascades and leukocyte recruitment as well as good clinical and serological response rates have led to the establishment of therapy with TNF $\alpha$ inhibitors in RA and other autoimmune disorders. Reduction of atherosclerotic complications relating to attenuation of the acute-phase response, including $\mathrm{C}$-reactive protein, platelet count, and fibrinogen, has been reported [22]. In light of the occurrence of serious side effects, though, the use of a nonselective blockade of all TNF $\alpha$ effects has been questioned.

In this study, we used the dorsal skinfold chamber microcirculatory model for in vivo assessment of arteriolar thrombosis and platelet-vessel wall interaction (PVWI) to investigate whether TNFa increases arteriolar thrombus formation in vivo, define the underlying platelet- or endothelium-mediated mechanisms, and specify TNF $\alpha$ receptor subtype-specific signaling.

\section{Materials and methods Chemicals}

Murine TNF $\alpha$ was from Chemicon International (now part of Millipore Corporation, Billerica, MA, USA), human TNF $\alpha$ was from ReliaTech (Wolfenbüttel, Germany), collagen was from Nycomed (now part of Takeda Pharmaceuticals International, Zürich, Switzerland), and antihuman tissue factor-FITC, anti-human P-selectin-RPE, and respective negative controls were from AbD Serotec (Oxford, UK). RNeasy Mini Kit, small interfering RNA (siRNA) against TNFR1 and TNFR2, and Effectene transfection kit were from Qiagen (Hilden, Germany), and predesigned glyceraldehyde-3-phosphate dehydrogenase (GAPDH), TNFR1, TNFR2, plasminogen activator inhibitor 1 (PAI-1), tissue factor, and thrombomudulin TaqMan primers were from Applied Biosystems (Foster City, CA, USA). All other chemicals were from Sigma-Aldrich (Munich, Germany).

\section{Animals}

Animal experiments were performed in wild-type (WT) or TNF $\alpha$ receptor-deficient C57BL/6 mice. WT mice were purchased from Charles River (Sulzfeld, Germany). TNFR $1^{-1-}$ and TNFR $2^{-/-}$mice were originally obtained from the Jackson Laboratory (Bar Harbor, ME, USA), and TNFR $1^{-1-} \mathrm{R} 2^{-/-}$mice were subsequently generated by cross-breeding. Surgical procedures were performed under short-term anesthesia induced by a single intraperitoneal injection of midazolam $3 \mathrm{mg} / \mathrm{kg}$ (Ratiopharm, Ulm, Germany), fentanyl $0.03 \mathrm{mg} / \mathrm{kg}$ (CuraMED Pharma, Baden-Württemberg, Germany), and medetomidinhydrochloride $0.3 \mathrm{mg} / \mathrm{kg}$ (Pfizer, Berlin, Germany; produced by Orion Pharma, Espoo, Finland) diluted in $0.9 \% \mathrm{NaCl}$. After the experiments, the animals were killed by injection of an overdose $(2 \mathrm{~g} / \mathrm{kg})$ of sodium pentobarbital (Merial, Hallbergmoos, Germany). All experiments were conducted in accordance with the German animal protection law and approved by the district government of Upper Bavaria (approval reference number AZ 55.2-1-54-2531-162-08). The investigation conforms to Directive 2010/63/EU of the European Parliament.

\section{Intravital microscopy in the dorsal skinfold chamber microcirculatory model}

The dorsal skinfold chamber microcirculatory model was used in mice as described previously [23]. Animals with an intact microcirculation underwent carotid artery catheterization for application of drugs or injection of isolated platelets, respectively. Intravital fluorescence microscopy was performed by using a modified microscope (Zeiss Axiotech Vario; Carl Zeiss, Oberkochen, Germany). Images were recorded with a digital camera (AxioCam HSm; Carl Zeiss). For all in vivo experiments, 
TNF $\alpha$ was administered via carotid artery catheter at a dose of $0.4 \mu \mathrm{g} / \mathrm{kg}$. This was calculated to match plasma levels of approximately $5 \mathrm{ng} / \mathrm{mL}$, which caused effects in vitro.

\section{Intravital assessment of arteriolar thrombosis}

Intravital thrombotic vessel occlusion time was assessed in arterioles of WT or TNF $\alpha$ receptor-deficient C57BL/6 mice in the dorsal skinfold chamber model. For induction of intra-arteriolar thrombosis, the ferric chloride superfusion method was used as described previously [23,24]. Before the experiments, blood vessel flow was digitally recorded and regular blood flow was confirmed for all analyzed arterioles. To visualize vessel lumina before vessel injury, $50 \mu \mathrm{L}$ of a $5 \%$ fluorescein isothiocyanatelabeled dextran solution (FITC-dextran, molecular weight $150,000)$ was infused via the carotid catheter. Injury to the vascular wall was then performed by application of $30 \mu \mathrm{L}$ of a ferric chloride solution $(25 \mathrm{mmol} / \mathrm{L})$ onto arterioles by using a standardized protocol, and movies were recorded until blood flow ceased.

\section{Mouse platelet isolation and staining for in vivo studies}

Whole blood was drawn from anesthetized mice by cardiac puncture. To prevent blood from clotting, syringes contained $10 \%$ of sodium citrate. The citrated whole blood was spun at $130 g$, and the obtained platelet-rich plasma (PRP) was incubated with carboxyfluorescin (carboxyfluorescein diacetate succinimidyl ester $17 \mu \mathrm{mol} / \mathrm{L}$; Bachem, Bubendorf, Switzerland) in the dark for 30 minutes. Labeled platelets were then spun at $340 \mathrm{~g}$ and resuspended in a buffered calcium-free physiologic solution (138 $\mathrm{mmol} / \mathrm{L} \mathrm{NaCl}, 2.7 \mathrm{mmol} / \mathrm{L} \mathrm{KCl}, 12 \mathrm{mmol} / \mathrm{L} \mathrm{NaHCO}_{3}$, $0.4 \mathrm{mmol} / \mathrm{L} \mathrm{NaH} \mathrm{NO}_{4}, 1 \mathrm{mmol} / \mathrm{L} \mathrm{MgCl}_{2} \times 6 \mathrm{H}_{2} \mathrm{O}$, $5 \mathrm{mmol} / \mathrm{L}$ D-glucose, $5 \mathrm{mmol} / \mathrm{L}$ Hepes; pH 7.35). For centrifugation, iloprost (10 ng/mL; Schering, Berlin-Wedding, Germany) was added to prevent platelet activation. The ability of the isolated and stained platelets to aggregate was tested by platelet aggregometry.

\section{Intravital analysis of platelet-vessel wall interaction}

For intravital studies of platelet interaction with the intact vessel wall, isolated and fluorescent-stained murine platelets from a donor animal were injected via a carotid artery catheter and observed in the dorsal skinfold chamber model. Movie sequences of 30 seconds in four- to sixvessel segments in each animal were recorded and analyzed by using AxioVision Software (Carl Zeiss). Vessels with abnormal flow were excluded from analysis. From the resulting length of the platelet trace in single images, velocities of single platelets were calculated by using the exposure time of each single picture. PVWI was expressed in frequency histograms consisting of all platelet velocities analyzed. Histograms were normalized to the maximum platelet speed within a vessel to exclude biasing influences of altered blood flow velocities between different arterioles. As a consequence, a rightward shift in platelet velocity distribution within a histogram expresses less PVWI, whereas a leftward shift signalizes increased PVWI at the arteriolar wall. Platelets with less than $5 \%$ of the velocity of the fastest platelets were defined as rolling platelets.

\section{Aggregation studies}

Platelet aggregation was measured by using the turbidimetric method described by Born [25]. Human or murine PRP was obtained by centrifugation $(130 g)$ of whole citrated blood drawn from human cubital veins or by cardiac puncture in mice. ADP-, collagen-, or thrombin receptor-activating peptide (TRAP)-induced platelet aggregation was measured photometrically by using a twochannel aggregometer (ChronoLog 490-2D; Chrono-log Corporation, Havertown, PA, USA) under continuous stirring at 1,000 revolutions per minute at $37^{\circ} \mathrm{C}$. Written consent was obtained from platelet donors. To assess the effects of endothelial-derived cytokines, $100 \mu \mathrm{L}$ of supernatant of stimulated human microvascular endothelial cells (HMECs) was added to $300 \mu \mathrm{L}$ of PRP and incubated for 90 minutes before agonist-induced aggregation was measured.

\section{Cell culture}

Human umbilical vein endothelial cells (HUVECs) were isolated and cultured as described previously [26]. The procedure was approved by a university ethics review board. HMECs were provided by Ades and colleagues [27] and cultured in M199 media supplemented with 10\% fetal calf serum, 10\% endothelial growth media (PromoCell, Heidelberg, Germany), and 1\% penicillin/streptomycin. The investigation conforms to the principles outlined in the Declaration of Helsinki.

\section{Measurement of endothelial superoxide $\left(\mathrm{O}_{2}{ }^{-}\right)$}

For superoxide measurements, the cytochrome c reduction method was used as previously described [28]. The $\mathrm{O}_{2}{ }^{-}$-dependent part of cytochrome $\mathrm{c}$ reduction was calculated from the difference in absorbance $(550 \mathrm{~nm})$ between samples incubated with or without superoxide dismutase.

\section{Endothelial surface molecule expression}

HMECs or HUVECs were grown as described and incubated with sham or TNF $\alpha(5 \mathrm{ng} / \mathrm{mL})$ as indicated. Cells were stained by using anti-p-selectin-RPE and anti-tissue factor-FITC or corresponding RPE- or FITC-labeled negative control. For measuring, a FACSCanto II flow cytometer (Becton, Dickinson and Company, Franklin Lakes, NJ, USA) was used. Data were analyzed by using FACSDiva software (Becton, Dickinson and Company). 
Real-time polymerase chain reaction in endothelial cells HMECs were incubated with sham or TNF $\alpha$ for indicated time points. RNA isolation and real-time polymerase chain reaction (PCR) were performed as described previously [29]. Commercially available pre-developed TaqMan reagents were used for the human target genes thrombomodulin, PAI-1, tissue factor, TNFR1, and TNFR2, and GAPDH was used as a reference housekeeping gene. All measurements were performed in duplicates.

\section{Endothelial-dependent blood clotting}

Cells were stimulated with TNF $\alpha$ as indicated and then lysed with $15 \mathrm{mM}$ n-octyl-D-glycopyranosidase in $0.1 \mathrm{M}$ imidazol buffer; $20 \mu \mathrm{L}$ of cell lysate and $20 \mu \mathrm{L}$ of $200 \mathrm{mmol} / \mathrm{L} \mathrm{CaCl} \mathrm{Cl}_{2}$ for re-calcification were added to $300 \mu \mathrm{L}$ of citrated (3.13\% sodium citrate) human whole blood from healthy volunteers, and clotting time was measured by thrombelastometry (Rotem; Tem Innovations, Munich, Germany). Stimulation with human recombinant tissue factor was used as a positive control.

\section{Role of autocrine factors}

To assess the role of TNF $\alpha$-induced autocrine factors released by endothelial cells, cells were stimulated with TNF $\alpha 5 \mathrm{ng} / \mathrm{mL}$ for 3 hours. After removal of the TNF $\alpha$ containing medium and a washing step, fresh medium without TNF $\alpha$ was added to the cells to allow secretion of prothrombotic factors. After 2 hours, this medium was used to stimulate untreated cells in which several parameters then were measured.

\section{Small interfering RNA knockdown}

Endothelial cells were transfected with $50 \mathrm{nM}$ siRNA against human TNFR1 and TNFR2 by using the magnetofection method in combination with the Effectene kit from Qiagen as previously described [30]. Transfected cells were left 48 hours to allow siRNA-mediated knockdown, which was confirmed by real-time PCR and Western blot, which was performed as described elsewhere [30].

\section{Statistical analysis}

SigmaStat Software (SYSTAT, Chicago, IL, USA) was used to calculate statistical differences. Data were analyzed by using Student $t$ test for normally distributed variables or the Mann-Whitney rank sum test, when normal distribution was not given. Data are expressed as mean \pm standard error of the mean. Differences were considered significant when the error probability level was a $P$ value of less than 0.05 .

\section{Results}

\section{Arteriolar thrombus formation in vivo}

To analyze the effect of TNF $\alpha$ on thrombus formation in vivo, we assessed the time to thrombotic arteriolar vessel occlusion following injury by ferric chloride superfusion to the vascular wall. The time to complete thrombotic vessel occlusion upon injury was significantly accelerated from $260 \pm 31$ seconds in control animals to $158 \pm 31$ seconds in animals treated with TNFa over a period of 4 hours prior to the experiment $(n=8$, $P<0.05$ versus control animals). Vessel occlusion time was not significantly accelerated compared with control animals when TNF $\alpha$ was given only half an hour prior to the experiment $(241 \pm 54$ seconds; $n=5$; Figure $1 \mathrm{a})$.

To investigate the contribution of signaling via the TNF $\alpha$ receptor subtypes, we measured time to thrombotic vessel occlusion in TNFR $1^{-/-}, \mathrm{TNFR}^{-/-}$, and TNFR1-/R2 ${ }^{-/-}$mice. The ability of TNF $\alpha$ to accelerate arteriolar thrombus formation in vivo observed in WT mice (Figure 1a) was further enhanced in TNFR $1^{-1-}$ mice, in which the mean vessel occlusion time after treatment with TNF $\alpha$ was reduced to $62 \pm 13$ seconds $(\mathrm{n}=5$, $P<0.05$ versus sham-treated TNFR $1^{-/-}$; Figure $2 \mathrm{a}$ ), corresponding to a TNF $\alpha$-dependent relative acceleration of thrombotic vessel occlusion time of $37 \% \pm 12 \%$ in WT mice and of $71 \% \pm 6 \%$ in TNFR $1^{-1-}$ mice ( $\mathrm{n}=5$ to $8 ; P<$ 0.05 versus WT treated with TNF $\alpha$; Figure $2 \mathrm{~b})$. In mice lacking TNFR2 or both TNFR1 and TNFR2, TNF $\alpha$ did not significantly accelerate thrombus formation in vivo. Without TNF $\alpha$ treatment, time to thrombotic vessel occlusion was not significantly affected in either of the TNF $\alpha$ receptor-deficient animals (Figure 2a).

\section{Platelet-endothelium interaction in vivo}

Next, we assessed transient interaction of platelets to the vessel wall in vivo by intravital microscopy of vessels in the dorsal skinfold chamber. Following systemic TNF $\alpha$ treatment, interaction of injected labeled platelets with the endothelium was slightly enhanced as indicated by a leftward shift in platelet flow velocities and a decrease in the median platelet velocity from $4.0 \mathrm{~mm} /$ second in control animals ( $\mathrm{n}=3,294$ platelets, 5 different animals) to $3.7 \mathrm{~mm} /$ second in TNF $\alpha$-treated animals $(\mathrm{n}=3,239$ platelets, 5 different animals, $P<0.05$ versus control animals). The fraction of rolling platelets (platelets with less than $5 \%$ of the blood flow velocity) was only $0.1 \% \pm 0.1 \%$ of all analyzed injected platelets in control animals and not significantly higher in TNF $\alpha$-treated animals, in which it was $0.4 \% \pm 0.6 \%$ ( $n=5$; data not shown).

In contrast, the leftward shift in platelet velocity pattern seen in WT mice after treatment with TNF $\alpha$ was much more prominent in TNFR1 $1^{-/-}$mice, indicating more interaction of platelets with the endothelium (Figure 3a). Moreover, TNF $\alpha$ increased the fraction of rolling platelets from $0.4 \% \pm 0.3 \%$ in WT mice to $4.1 \% \pm 1.0 \%$ in $\mathrm{TNFR}^{-1-}$ mice ( $\mathrm{n}=5, \mathrm{P}<0.01$ versus WT; Figure $3 \mathrm{~b}$ ). In TNF $\alpha$ treated TNFR2 $2^{-/-}$animals, the fraction of rolling platelets was not significantly different compared with WT mice 


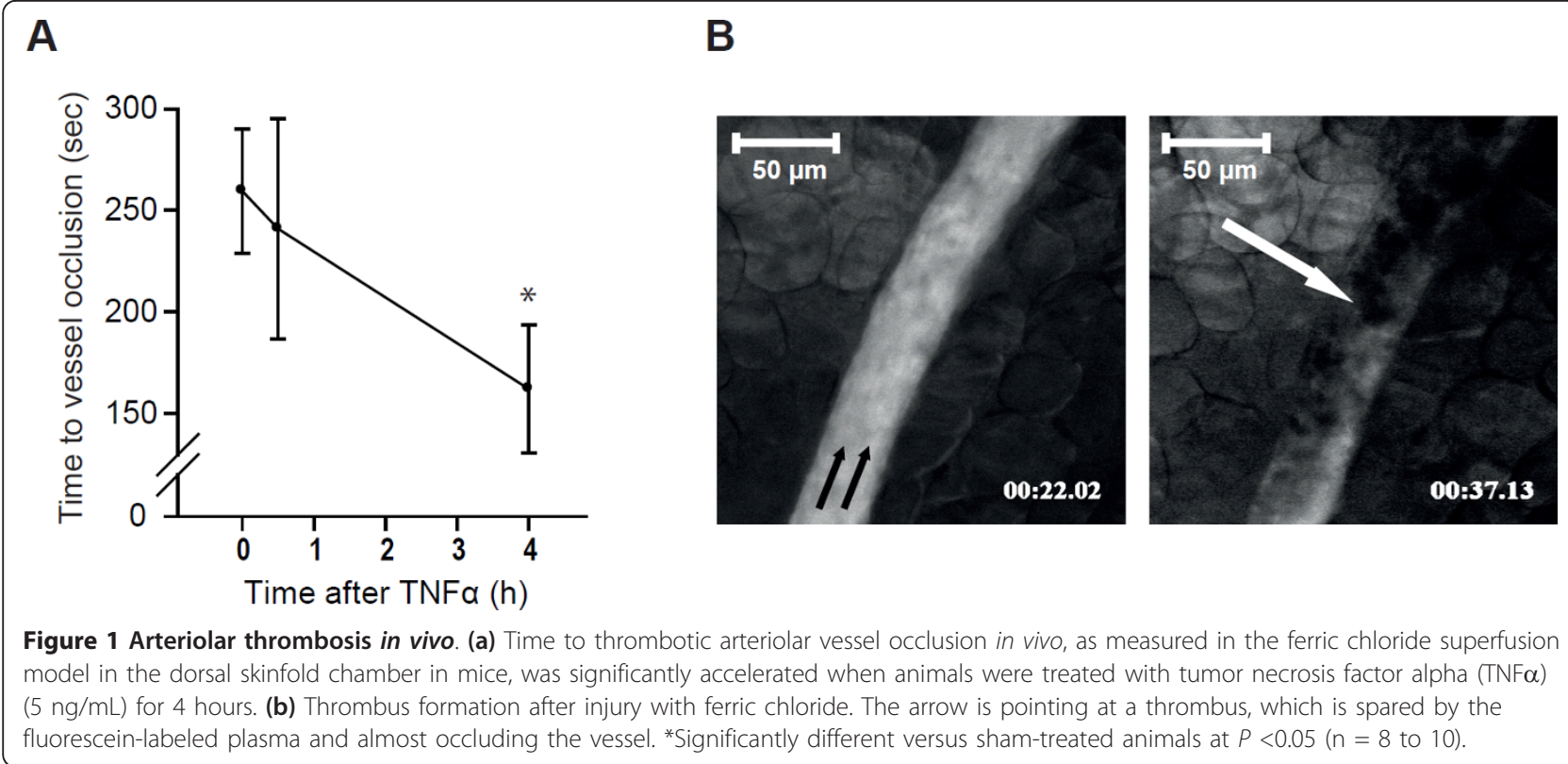

$(1.1 \% \pm 0.4 \%)$. The maximum platelet velocities in the analyzed vessels as an approximate measure of flow velocity were not significantly different before and after TNF $\alpha$ treatment or between the genotypes.

\section{Platelet aggregation in platelet-rich plasma}

To test for direct effects of TNF $\alpha$ on platelets, we assessed platelet aggregation in vitro in human PRP by using light transmission aggregometry (Born's method). Incubation of PRP with TNF $5 \mathrm{ng} / \mathrm{mL}$ for different time intervals did not affect the ability of platelets to form aggregates upon stimulation with several commonly used platelet agonists - ADP $(5 \mu \mathrm{mol} / \mathrm{L})$, collagen ( 5 to $10 \mu \mathrm{g} / \mathrm{mL})$, or TRAP $(5 \mu \mathrm{mol} / \mathrm{L})$ - either after a short time of incubation or after 4 hours $(n=8$; results for ADP in Figure 4a). TNF $\alpha$ itself did not cause platelet
A

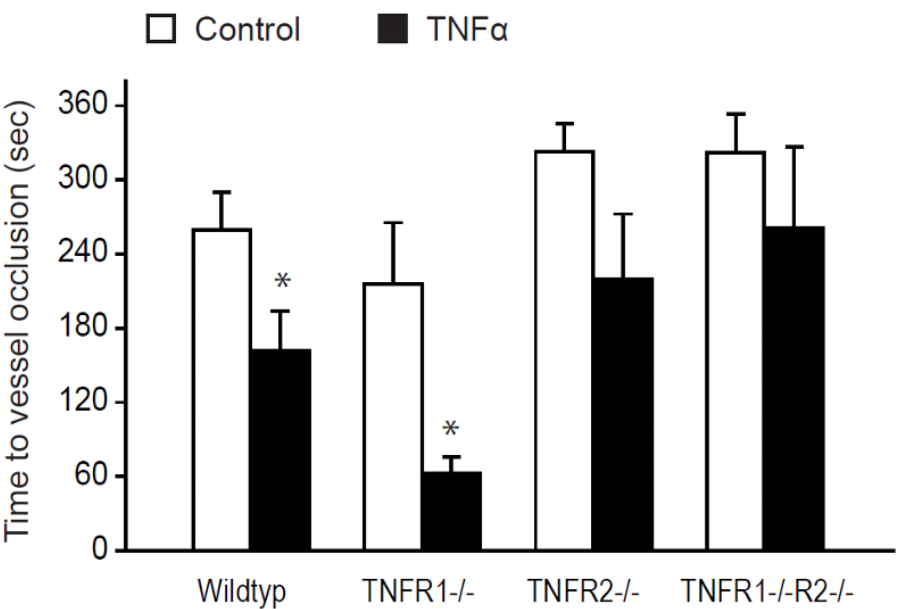

B

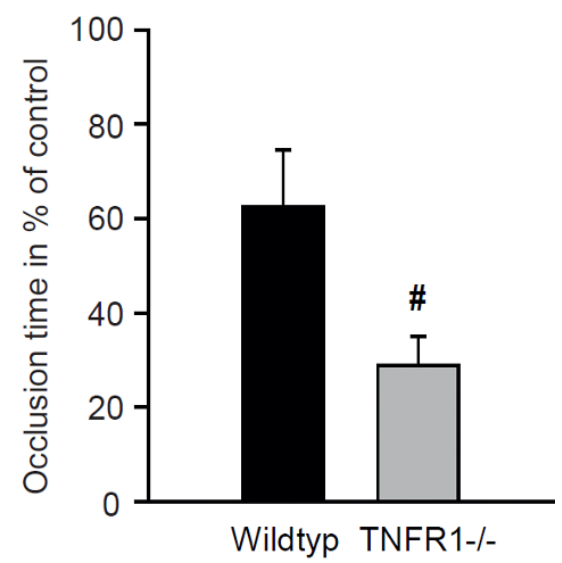

Figure 2 Tumor necrosis factor alpha (TNF $\alpha$ )-induced arteriolar thrombosis in vivo is increased in TNFR1-deficient mice. (a) Thrombotic arteriolar vessel occlusion in vivo was most accelerated with TNF $\alpha$ ( $5 \mathrm{ng} / \mathrm{mL}, 4$ hours) in TNFR1-deficient mice. In mice lacking TNFR2 only or both TNF receptor subtypes, TNF $\alpha$ did not significantly affect arteriolar thrombosis. (b) In TNFR ${ }^{-1-}$ mice, the relative acceleration of arteriolar thrombus formation by TNF $\alpha$ was significantly stronger compared with wild-type mice. *Significantly different versus respective sham-treated animals at $P<0.05$ ( $\mathrm{n}=5$ to 10$)$. " Significantly different versus wild-type at $P<0.05(\mathrm{n}=5)$. TNF $\alpha$, tumor necrosis factor alpha; TNFR1, tumor necrosis factor alpha receptor subtype 1; TNFR2, tumor necrosis factor alpha receptor subtype 2. 

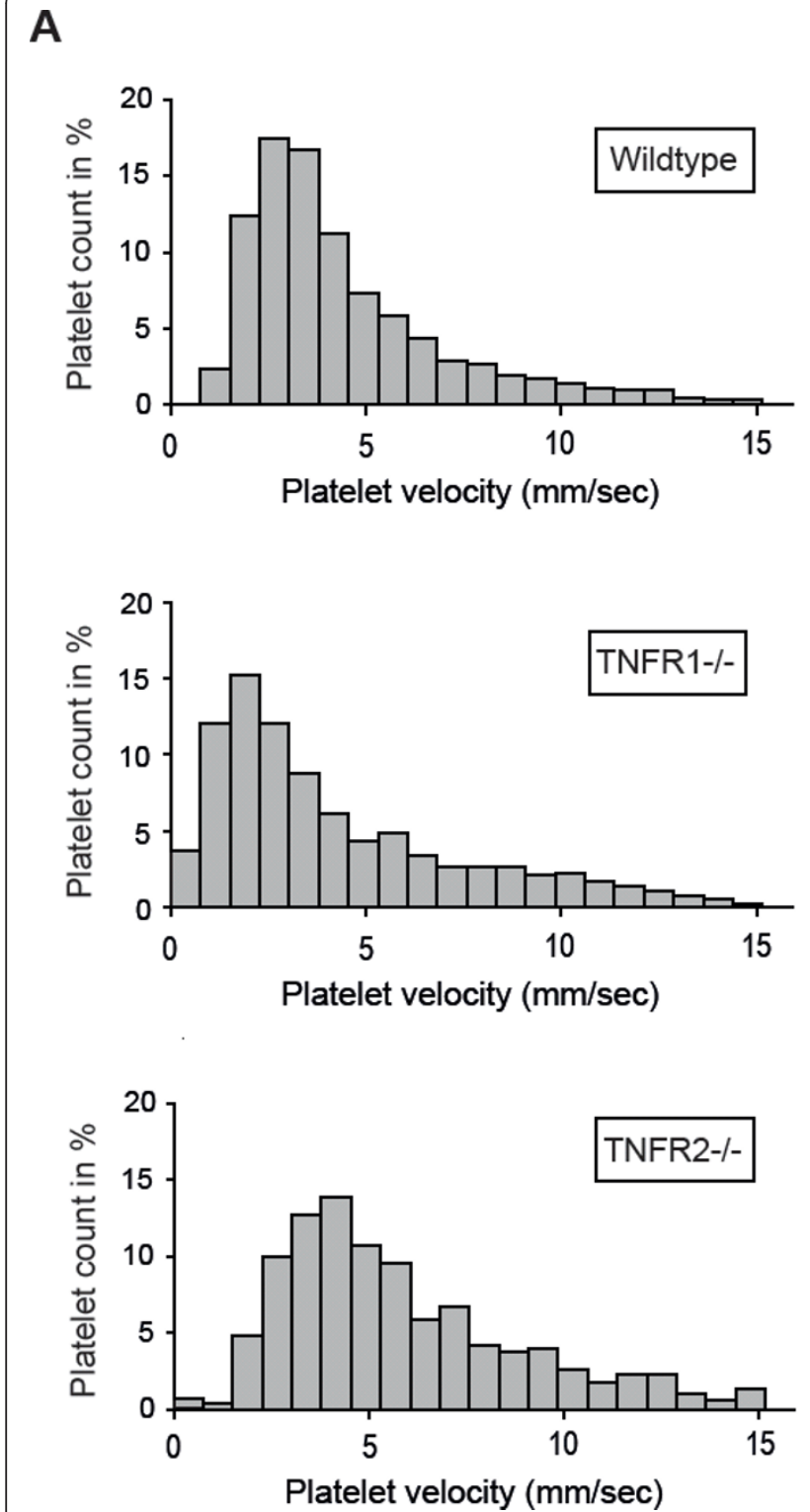

B

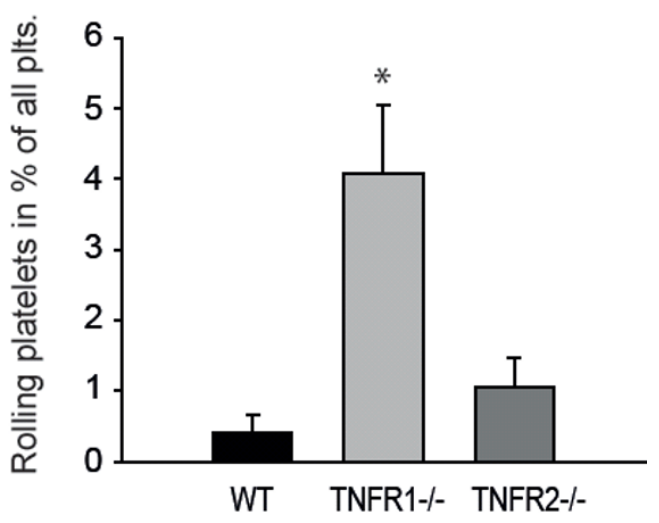

C
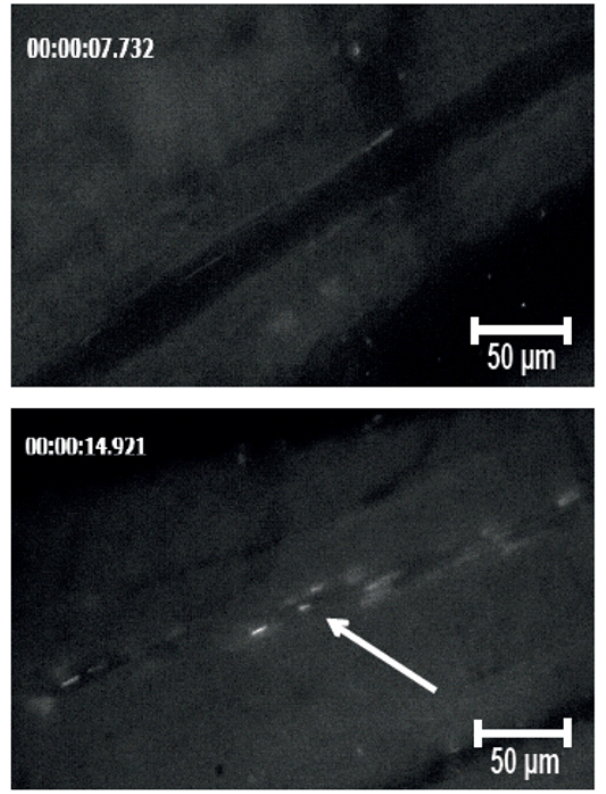

Figure 3 Tumor necrosis factor alpha (TNF $\alpha$ ) increases platelet-endothelium interaction and platelet rolling in vivo in TNFR1-deficient mice. (a) in vivo platelet-endothelium interaction as analyzed by intravital microscopy in the dorsal skinfold chamber was greatly enhanced in $\mathrm{TNFR}^{-1-}$ mice pretreated with TNF $\alpha$ (5 ng/mL, 4 hours) compared with wild-type (WT) or TNFR2 ${ }^{-1-}$ mice treated likewise, as indicated by a leftward shift in platelet velocity distribution pattern in the frequency histogram of analyzed platelet velocities. (b) When rolling platelets (defined as platelets with velocity of less than $5 \%$ of maximum velocity) were quantified after TNF $\alpha$ treatment, the fraction related to all analyzed platelets was significantly higher in mice lacking TNFR1 compared with WT or TNFR2-deficient animals. (c) Digital records of carboxyfluorescein-labeled platelets in arterioles with increased platelet-endothelium interaction and rolling platelets (arrow). *Significantly different versus WT and TNFR2 ${ }^{-1-}$ mice at $P<0.01$ ( $n=3$ to 5). plts, platelets; TNFR1, tumor necrosis factor alpha receptor subtype 1 ; TNFR2, tumor necrosis factor alpha receptor subtype 2.

aggregation either. Also, the addition of supernatant of TNF $\alpha$-treated endothelial cells (with or without siRNA knockdown of TNFR1 or TNFR2) to PRP had no influence on platelet aggregation $(n=4$; Figure $4 \mathrm{~b})$.

To check whether direct activation of platelets is responsible for prothrombotic TNF $\alpha$ effects in TNFR1 $1^{-/-}$ mice, we performed platelet aggregation studies ex vivo in PRP from TNFR1 $1^{-/-}$mice. Like in human PRP, platelets from these animals showed no differences in the ability to aggregate with or without prior TNF $\alpha$ incubation ( $5 \mathrm{ng} / \mathrm{mL}$ ) to different stimuli, including ADP and collagen, at different stimulation times $(n=5$; Figure $4 c)$. 


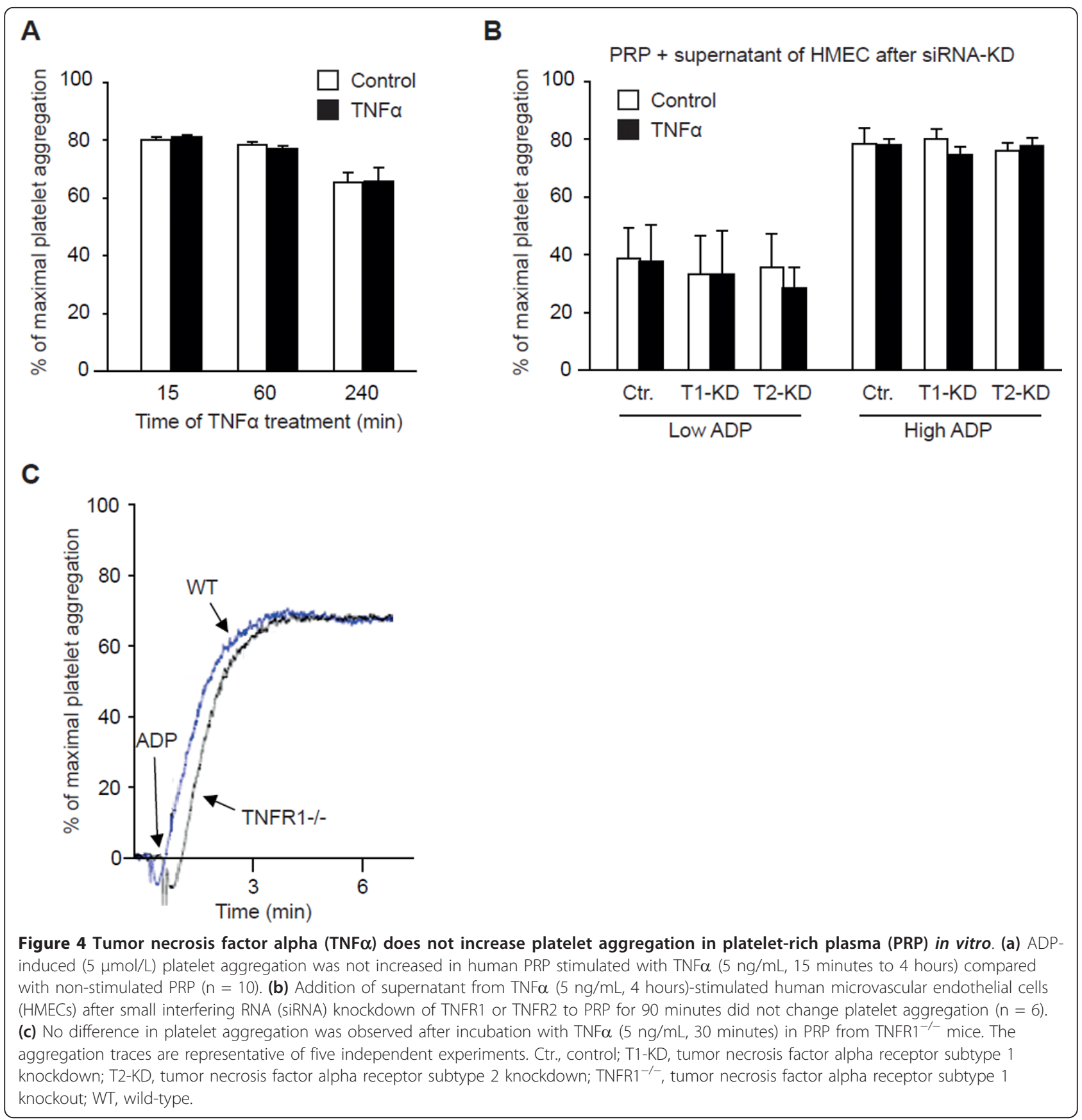

\section{TNF $\alpha$-induced prothrombotic changes in endothelial cells in vitro}

To better define the relative contribution of the endothelium to TNF $\alpha$-dependent prothrombotic effects, we analyzed pro- and anti-coagulant factors in primary human endothelial cells (HUVECs) and HMECs. We first measured the release of endothelial superoxide $\left(\mathrm{O}_{2}{ }^{-}\right)$upon TNF $\alpha$ stimulation in HUVECs by using the cytochrome c assay. The photometrically recorded superoxide dismutase-sensitive fraction of cytochrome c reduction, expressed as the difference in the absorbance, depicts the production of $\mathrm{O}_{2}{ }^{-}$and was $2.2 \pm 0.6$-fold increased after stimulation with TNF $\alpha$ for half an hour in a dose of $5 \mathrm{ng} / \mathrm{mL}$ ( $\mathrm{n}=15, P<0.05$ versus control; Figure $5 \mathrm{a}$ ).

Next, we used flow cytometry to measure the adhesion molecule p-selectin, which is described to mediate platelet rolling on the endothelium [31]. Whereas p-selectin was barely detectable on the surface membrane of HUVECs either non-stimulated or stimulated with TNF $\alpha(5 \mathrm{ng} / \mathrm{mL})$ for only 30 minutes, it was significantly upregulated after 


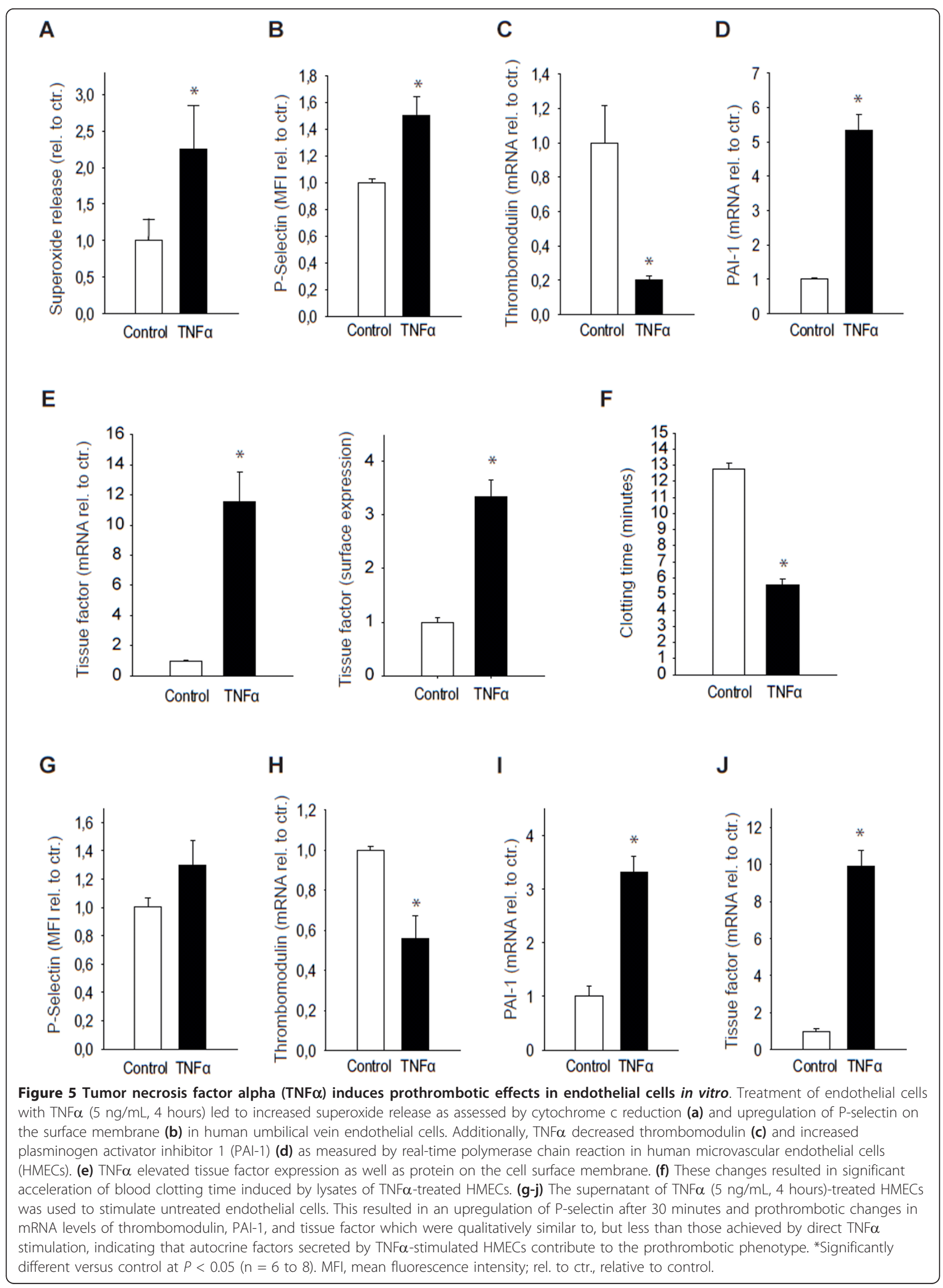


4 hours, with an increase in the mean relative fluorescence of $50.4 \% \pm 13.7 \%(P<0.05, \mathrm{n}=5$; Figure $5 \mathrm{~b})$.

Thrombomodulin expression was found to be suppressed by $79.8 \% \pm 2.4 \%$ upon treatment with TNF $\alpha$ $5 \mathrm{ng} / \mathrm{mL}$ for 4 hours $(P<0.05, \mathrm{n}=8$; Figure $5 \mathrm{c})$. Furthermore, PAI-1, one of the most potent inhibitors of fibrinolysis, and tissue factor (CD142), which plays a crucial role in the activation of the extrinsic pathway of the coagulation cascade, were measured by real-time PCR in HMECs upon stimulation with TNF $\alpha$ for 30 minutes or 4 hours at $5 \mathrm{ng} / \mathrm{mL}$. After 4 hours, mRNA levels of PAI-1 were more than fivefold higher compared with baseline (fold increase $5.3 \pm 0.5 ; P<0.05, \mathrm{n}=16$; Figure $5 \mathrm{~d}$ ), and both tissue factor expression and tissue factor protein on the surface membrane of HMECs were significantly upregulated after 4 hours of treatment with TNF $\alpha \mathrm{ng} / \mathrm{mL}$ (11.6 \pm 2.0 -fold and $3.4 \pm 0.3$-fold increase versus baseline, respectively, $P<0.05, \mathrm{n}=8$ to 10 ; Figure 5e). Ultimately, in an endothelial-dependent clotting assay in whole blood, clotting time upon induction with HMEC lysates after stimulation with $\mathrm{TNF} \alpha(5 \mathrm{ng} / \mathrm{mL}$ for 4 hours) was accelerated from $12.5 \pm 0.3$ minutes to $5.5 \pm$ 0.4 minutes $(P<0.05, \mathrm{n}=4$; Figure $5 \mathrm{f})$.

\section{Endothelium-derived mediators induce prothrombotic molecules}

To test whether endothelial cells stimulated with TNF $\alpha$ secrete mediators which contribute to TNF $\alpha$-dependent prothrombotic effects, HUVECs or HMECs were incubated for 30 minutes (for p-selectin) and 4 hours (for thrombomodulin, PAI-1, and tissue factor expression) with supernatants of cells previously stimulated with TNF $\alpha$ at $5 \mathrm{ng} / \mathrm{mL}$ for 3 hours. Whereas p-selectin was slightly but not significantly increased $(\mathrm{n}=6$; Figure $5 \mathrm{~g})$, expression levels of thrombodulin were reduced by $44 \% \pm$ $12 \%(P<0.05, \mathrm{n}=4$; Figure $5 \mathrm{~h})$, and mRNA levels of PAI-1 and tissue factor were significantly increased $(3.3 \pm$ 03-fold and $9.9 \pm 0.8$-fold increase versus baseline, respectively, $P<0.05, \mathrm{n}=4$; Figure $5 \mathrm{i}, \mathrm{j})$.

\section{Relative contribution of TNFR1 and TNFR2 in mediation of TNF $\alpha$-dependent prothrombotic effects in vitro}

To define the relative contribution of the TNFR subtypes to induction of single genes relevant in thrombosis, knockdowns of TNFR1 and TNFR2 were performed in HMECs and HUVECs by using siRNA. As tested by real-time PCR and Western blot after 24 and 48 hours, respectively, for both receptors, a knockdown of about $55 \%$ could be achieved (Figure $6 \mathrm{j}$ ).

Whereas upregulation of p-selectin was inhibited only by knockdown of TNFR2 (Figure 6a), TNF $\alpha$-dependent changes in thrombomodulin and PAI-1 expression were significantly reduced by TNFR1 knockdown (Figure 6b,c).
TNF $\alpha$-induced upregulation of tissue factor was significantly reduced by knockdown of both TNFR subtypes (Figure 6d).

Thrombomodulin suppression induced by the supernatant of TNF $\alpha$-stimulated HMECs was abolished after TNFR2 knockdown ( $\mathrm{n}=4$; Figure $6 \mathrm{f})$, and $\mathrm{p}$-selectin, PAI-1, and tissue factor upregulations induced by soluble mediators released upon TNF $\alpha$ stimulation were not changed after knockdown of either of the TNF receptor subtypes $(\mathrm{n}=4$; Figure $6 \mathrm{e}, \mathrm{g}, \mathrm{h})$. Knockdown of both TNFR1 and TNFR2 significantly inhibited endothelialdependent TNF $\alpha$-induced acceleration of blood clotting $(P<0.05, \mathrm{n}=4$; Figure 6i $)$.

\section{Discussion}

This study provides evidence of TNF $\alpha$ significantly accelerating ferric chloride-induced thrombus formation in an in vivo mouse model for arteriolar thrombosis. Its prothrombotic effects in vivo require the endothelial expression of TNFR2 and are more pronounced in the absence of TNFR1. in vitro studies indicate endothelial mechanisms to be responsible for prothrombotic TNF $\alpha$ effects, including an enhanced endothelial production of reactive oxygen species; upregulation of p-selectin, tissue factor, and PAI-1 expression; and suppression of thrombomodulin. TNF $\alpha$ results in the release of soluble mediators by endothelial cells which induce prothrombotic and suppress anticoagulant genes similar to direct TNF $\alpha$-effects, but to a lesser extent. The early occlusion of capillary vessels might well be relevant in autoimmune disorders, as both endothelial cell activation and an enhanced influx of inflammatory cells are able to promote disease manifestations, and, in fact, microvessel changes have been a long-standing diagnostic tool in nailfold capillary microscopy and are well defined in lupus nephritis.

Our findings are consistent with the previously characterized direct effects of TNF $\alpha$ on endothelial cells, such as the induction of pro-inflammatory cytokines, fibrin deposition, and an increase in permeability [15-17,32]. In contrast, ex vivo platelet aggregation in our study was not influenced either by TNF $\alpha$ itself or by soluble mediators released by endothelial cells upon stimulation with TNF $\alpha$. Of note, a weak direct activation of platelets by TNF $\alpha$ has been described [33,34]; indeed, from our in vivo results, we cannot exclude a direct effect of TNFa on platelets. In regard to our in vivo studies, we do explicitly consider our results not to be conflicting with the prior experimental evidence for antithrombotic activity of TNFa in a short time stimulation protocol [35]. In our model of arteriolar thrombosis, we observed a significantly accelerated time to thrombotic vessel occlusion upon injury 4 hours after systemic treatment with TNFa, 


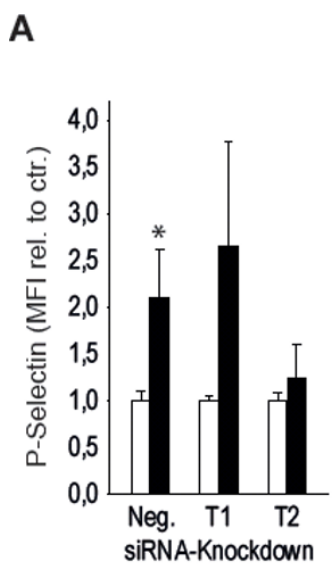

E

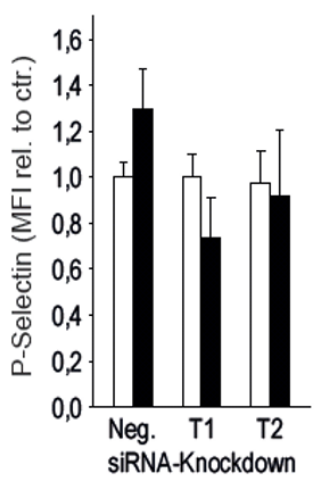

I

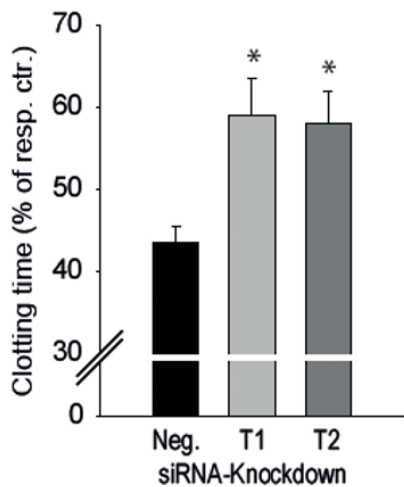

B

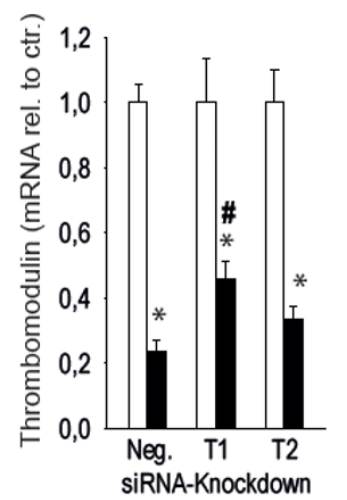

$\mathbf{F}$

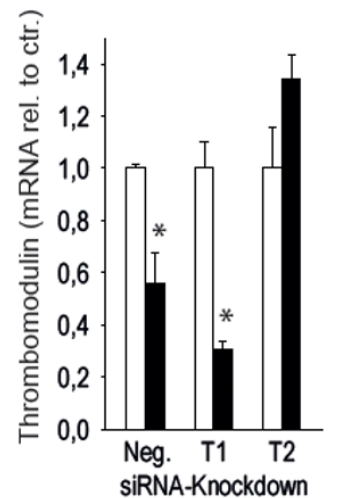

C

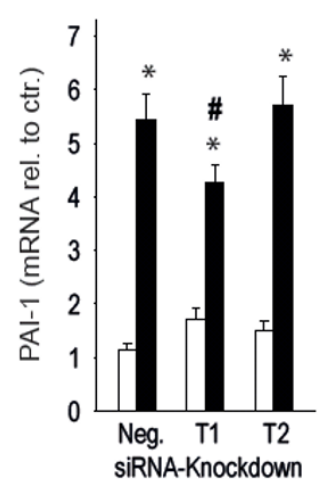

G

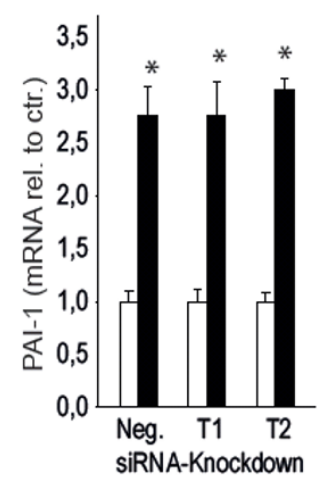

D

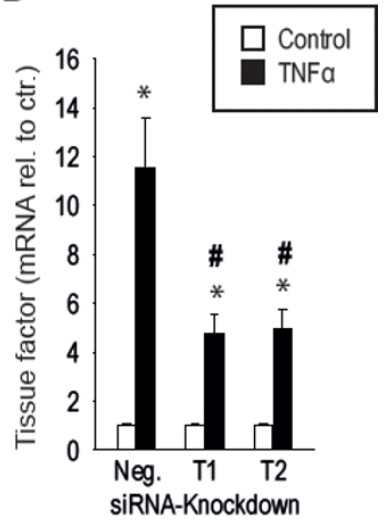

H

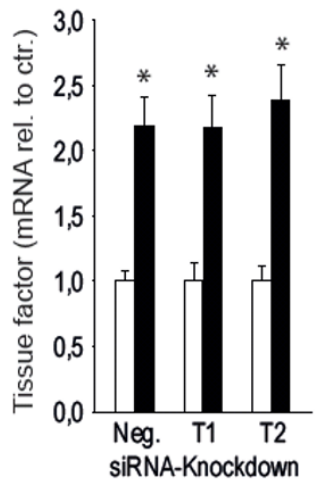

J
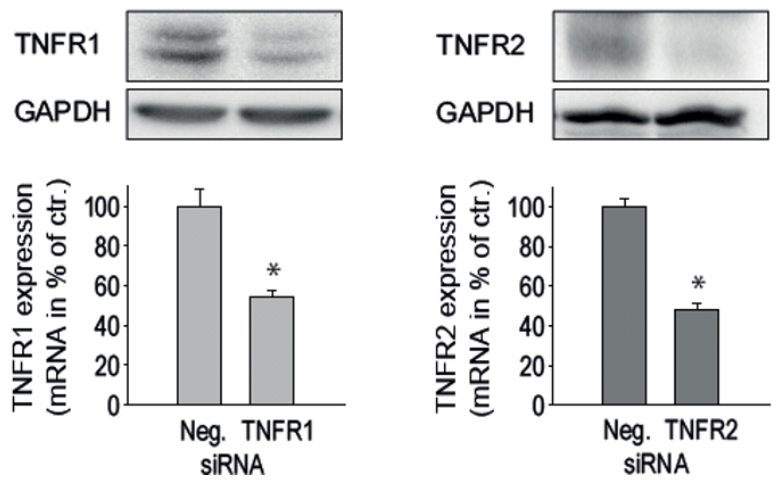

Figure 6 Contribution of tumor necrosis factor (TNF) receptor subtypes to prothrombotic effects in endothelial cells in vitro. (a) TNF $\alpha$ ( $5 \mathrm{ng} / \mathrm{mL}$, 4 hours)-induced upregulation of P-selectin is significantly reduced after TNFR2 knockdown. Whereas TNF $\alpha$-dependent prothrombotic changes in thrombomodulin and plasminogen activator inhibitor 1 (PAl-1) expression were only reduced after TNFR1 knockdown (b, c), single knockdown of TNFR1 and TNFR2 both significantly reduced TNF $\alpha$-induced generation of tissue factor (d) and eventually acceleration of blood clotting induced by human microvascular endothelial cell (HMEC) lysates (i). (e-h) The contribution of secreted autocrine factors (as assessed by stimulation with the supernatant of TNF $\alpha$ ( $5 \mathrm{ng} / \mathrm{mL}$, 4 hours)-treated HMECs) to upregulation of P-selectin, PAl-1, and tissue factor was not changed after specific TNF receptor knockdown, while reduction of thrombomodulin was inhibited after knockdown of TNFR2. (j) Knockdown of TNFR1 (left) and TNFR2 (right) was achieved by small interfering RNA (siRNA) and magnetofection and was confirmed on mRNA as well as protein level as measured by real-time polymerase chain reaction and Western blot after 24 and 48 hours, respectively. *Significantly different versus respective control at $P<0.05$. "Significantly different versus control-transfected cells treated with TNF $\alpha$ ( $\mathrm{n}=4$ to 8 independent experiments). ctr., control; GAPDH, glyceraldehyde-3-phosphate dehydrogenase; MFI, mean fluorescence intensity; Neg., negative; rel. to ctr., relative to control; resp. ctr., respective control; TNFR1, tumor necrosis factor alpha receptor subtype 1; TNFR2, tumor necrosis factor alpha receptor subtype 2. 
and this is consistent with other studies of thrombosis in an inflammatory milieu [36]; after 30 minutes, neither pro- nor anti-thrombotic effects were seen, and this could be explained by differences in the injury model as well as in the vascular bed.

In this work, we compared arteriolar thrombus formation and platelet-endothelium interaction in mice deficient in TNFR1 or TNFR2 and animals lacking both TNF $\alpha$ receptor subtypes. Just as the site- and timedependent context of its release, the complex interplay between TNF $\alpha$ receptor subtypes is pivotal in defining the actual effect of TNFa [3]. In addition, though sharing the same signaling pathways, responses of immune cells differ from those of non-immune cells, which ultimately cause organ-specific pathology in chronic inflammation [37] and hence represent equally important targets in the therapy of autoimmune diseases. Not only is the expression of TNFR2 highly regulated, but the stimulation of TNFR2 encompasses the induction of endogenous TNF $\alpha$, and reverse signaling through tmTNF $\alpha$ that influences expression of cytokines and adhesion molecules in the tmTNF $\alpha$-bearing cell has been described [38]. In regard to vascular biology in particular, TNFR2 seems to be crucial for both TNF $\alpha$-induced atherosclerotic lesions in mouse models for atherosclerosis [39-41] and leukocyte interaction with the endothelium [42]. Our observations indicate that TNFR2 is required to mediate the prothrombotic effects of TNF $\alpha$ in vivo, whereas TNFR1 partly compensates these effects, since the prothrombotic effect of TNFa is potentiated in TNFR1 knockout mice when compared with WT animals. However, activation of TNFR1 does not seem to have antithrombotic activity itself but is merely able to attenuate the prothrombotic effects mediated by activation of TNFR2; indeed, TNFR2 knockout mice do not show a significantly longer vessel occlusion time than mice either not pretreated with TNF $\alpha$ or lacking both TNFR subtypes.

As platelets from TNFR1-deficient mice ex vivo do not aggregate more than WT platelets, TNFR2-mediated prothrombotic effects in vivo are likely not to rely on direct effects on platelets. Hence, we investigated TNF $\alpha$ dependent changes in the expression of prothrombotic molecules in endothelial cells in vitro after siRNA knockdown of TNFR1 or TNFR2. According to the conclusion from the in vivo experiments, in which prothrombotic effects required TNFR2 and were more pronounced in the absence of TNFR1, mediators of a procoagulant milieu were expected to be less inducible by TNF $\alpha$ in the TNFR2 knockdown cells. This could be confirmed for p-selectin; however, TNF $\alpha$-dependent induction of PAI-1 and suppression of thrombomodulin seemingly depended predominantly on TNFR1, while both TNFR subtypes were required for the upregulation of tissue factor and endothelial-dependent clotting. Interestingly, normal expression of TNFR2 was also necessary for the secretion of soluble mediators causing the suppression of thrombomodulin. Discrepancies to in vivo experiments can be explained by the incomplete receptor knockdown in vitro, which implicates a persistent interplay between the receptor subtypes. In addition, the analysis of single target genes in the endothelium certainly does not entirely reflect the complex setting of inflammation and coagulation in vivo.

With respect to clinical implications, the relevance of experimental results to most clinical conditions in humans is not clear as the majority of studies have been done in genetically deficient mice. However, anticytokine approaches with soluble receptor antagonists and monoclonal antibodies have become a mainstay in therapy of RA and other chronic inflammatory diseases. So far, there is no evidence of an increase in thrombotic events in patients treated with TNF $\alpha$ antagonists [43]. In this context, the finding that prothrombotic TNF $\alpha$ effects are mediated by TNFR2 is intriguing as deterioration of microcirculation in inflammation could well be relevant with respect to drug delivery, particularly prone to be compromised at the sites defined as therapeutic targets. Maintenance or reconstitution of an unhampered blood flow should be attained particularly well by a more selective therapeutic approach consisting of a TNFR2-specific antagonist. The implementation of TNFR2-specific antagonists has already been advocated because the highly regulated receptor subtype TNFR2 mediates tissue damage in chronic inflammation. A selective blockade of TNFR2 would also allow downregulation of excessive TNF $\alpha$ signaling in uncontrolled inflammatory processes while leaving unaffected beneficial TNF $\alpha$ effects. In addition, amplification of TNFR1 responses by ligand passing and reverse signaling through tmTNF $\alpha$ would both be abolished by antagonizing TNFR2. Still, with regard to the improvement of therapeutic strategies, we consider the observation of soluble, endothelium-derived mediators to be very important as they presumably allow a local amplification of prothrombotic responses in inflammation.

\section{Conclusions}

We hereby provide evidence for prothrombotic effects of the inflammatory cytokine TNF $\alpha$. In our in vivo model of arteriolar thrombosis, both prothrombotic effects and increased platelet rolling are mediated through endothelial TNFR subtype 2 and partly compensated for by TNFR subtype 1 . In vitro, both TNF $\alpha$ itself and a TNF $\alpha$-induced release of soluble mediators led to an induction of prothrombotic and a suppression of anticoagulant molecules in human endothelial cells, resulting in an accelerated clotting time in endothelial cell-based assays. Assuming that the occlusion of capillary vessels in autoimmune disorders is relevant well beyond mere thrombosis, we argue in 
favor of a more selective therapeutic approach in anticytokine therapy based on TNFR2-specific antagonists.

\begin{abstract}
Abbreviations
FITC: fluorescein isothiocyanate; GAPDH: glyceraldehyde-3-phosphate dehydrogenase; HMEC: human microvascular endothelial cell; HUVEC: human umbilical vein endothelial cell; NF-KB: nuclear factor-kappa-B; PAI-1: plasminogen activator inhibitor 1; PCR: polymerase chain reaction; PRP: platelet-rich plasma; PVWI: platelet-vessel wall interaction; RA: rheumatoid arthritis; RPE: R-phycoerythrin; siRNA: small interfering RNA; tmTNFa: transmembrane tumor necrosis factor alpha; TNFa: tumor necrosis factor alpha; TNFR1: tumor necrosis factor alpha receptor subtype 1; TNFR2: tumor necrosis factor alpha receptor subtype 2; TRAP: thrombin receptor-activating protein; WT: wild-type.
\end{abstract}

\section{Acknowledgements}

This work was supported by a grant from the 'Förderprogramm für Forschung und Lehre' of the Ludwig Maximilians University, grant WO 1716/ 1-1 of the 'Deutsche Forschungsgemeinschaft' (DFG), and a grant from the Else Kröner-Fresenius-Stiftung and the Wilhelm-Vaillant-Stiftung. This paper contains part of Joachim Pircher's doctoral thesis, which was approved by the medical faculty of the Ludwig Maximilians University Munich.

\section{Author details}

${ }^{1}$ Medizinische Klinik und Poliklinik IV, Innenstadt, Ludwig Maximilians University München, Ziemssenstr. 1, 80336 Munich, Germany. ${ }^{2}$ Walter Brendel Centre of Experimental Medicine, Ludwig Maximilians University München, Marchioninistr. 27, 81377 Munich, Germany. ${ }^{3}$ Department of Gynecology, Klinikum rechts der Isar, Technische Universität München, Ismaninger Strasse 22, Munich, Germany. ${ }^{4}$ Invasive Cardiology, Clinic Starnberg, Oßwaldstr. 1, 82319 Munich, Germany.

\section{Authors' contributions}

JP designed the study, performed the in vivo experiments, and wrote the manuscript. MM and MW wrote the manuscript and analyzed and interpreted the data. TC and YS performed in vivo experiments. HM, AR, and MN did the in vitro experiments. W provided the knockout mice and revised the manuscript. FK closely supervised the study and did the final revision for intellectual content. All authors read and approved the final manuscript.

\section{Competing interests}

The authors declare that they have no competing interests.

Received: 16 February 2012 Revised: 31 August 2012

Accepted: 5 October 2012 Published: 18 October 2012

\section{References}

1. Aggarwal BB: Signalling pathways of the TNF superfamily: a doubleedged sword. Nat Rev Immunol 2003, 3:745-756.

2. Holtmann MH, Neurath MF: Differential TNF-signaling in chronic inflammatory disorders. Curr Mol Med 2004, 4:439-444

3. Locksley RM, Killeen N, Lenardo MJ: The TNF and TNF receptor superfamilies: integrating mammalian biology. Cell 2001, 104:487-501.

4. Aggarwal BB, Gupta SC, Kim JH: Historical perspectives on tumor necrosis factor and its superfamily: 25 years later, a golden journey. Blood 2012, 119:651-665.

5. Arch RH, Gedrich RW, Thompson CB: Tumor necrosis factor receptorassociated factors (TRAFs)-a family of adapter proteins that regulates life and death. Genes Dev 1998, 12:2821-2830.

6. Brennan FM, McInnes IB: Evidence that cytokines play a role in rheumatoid arthritis. J Clin Invest 2008, 118:3537-3545.

7. Feldmann M, Brennan FM, Maini RN: Role of cytokines in rheumatoid arthritis. Annu Rev Immunol 1996, 14:397-440.

8. Systemic sclerosis: current pathogenetic concepts and future prospects for targeted therapy. Lancet 1996, 347:1453-1458.

9. Aringer M, Smolen JS: The role of tumor necrosis factor-alpha in systemic lupus erythematosus. Arthritis Res Ther 2008, 10:202.

10. Libby P: Role of inflammation in atherosclerosis associated with rheumatoid arthritis. Am J Med 2008, 121:S21-31.
11. Maradit-Kremers H, Nicola PJ, Crowson CS, Ballman KV, Gabriel SE: Cardiovascular death in rheumatoid arthritis: a population-based study. Arthritis Rheum 2005, 52:722-732.

12. Solomon DH, Karlson EW, Rimm EB, Cannuscio CC, Mandl LA, Manson JE, Stampfer MJ, Curhan GC: Cardiovascular morbidity and mortality in women diagnosed with rheumatoid arthritis. Circulation 2003, 107:1303-1307.

13. Ross R: Atherosclerosis-an inflammatory disease. N Engl J Med 1999, 340:115-126.

14. Libby P: Inflammation in atherosclerosis. Nature 2002, 420:868-874.

15. Zhang H, Park Y, Wu J, Chen X, Lee S, Yang J, Dellsperger KC, Zhang C: Role of TNF-alpha in vascular dysfunction. Clin Sci (Lond) 2009, 116:219-230.

16. Gao X, Belmadani S, Picchi A, Xu X, Potter BJ, Tewari-Singh N, Capobianco S, Chilian WM, Zhang C: Tumor necrosis factor-alpha induces endothelial dysfunction in Lepr(db) mice. Circulation 2007, 115:245-254.

17. Kumar A, Takada Y, Boriek AM, Aggarwal BB: Nuclear factor-kappaB: its role in health and disease. J Mol Med 2004, 82:434-448.

18. Esmon CT: Inflammation and thrombosis. J Thromb Haemost 2003, 1:1343-1348

19. Conway EM: Thrombomodulin and its role in inflammation. Semin Immunopathol 2012, 34:107-125.

20. Wagner DD, Burger PC: Platelets in inflammation and thrombosis. Arterioscler Thromb Vasc Biol 2003, 23:2131-2137.

21. Gawaz M, Langer H, May AE: Platelets in inflammation and atherogenesis. J Clin Invest 2005, 115:3378-3384.

22. Jacobsson LT, Turesson C, Gulfe A, Kapetanovic MC, Petersson IF, Saxne T, Geborek P: Treatment with tumor necrosis factor blockers is associated with a lower incidence of first cardiovascular events in patients with rheumatoid arthritis. J Rheumatol 2005, 32:1213-1218.

23. Struthmann L, Hellwig N, Pircher J, Sohn HY, Buerkle MA, Klauss V, Mannell H, Pohl U, Krotz F: Prothrombotic effects of diclofenac on arteriolar platelet activation and thrombosis in vivo. J Thromb Haemost 2009, 7:1727-1735.

24. Buerkle MA, Lehrer S, Sohn HY, Conzen P, Pohl U, Krotz F: Selective inhibition of cyclooxygenase- 2 enhances platelet adhesion in hamster arterioles in vivo. Circulation 2004, 110:2053-2059.

25. Born GV: Aggregation of blood platelets by adenosine diphosphate and its reversal. Nature 1962, 194:927-929.

26. Mannell H, Hammitzsch A, Mettler R, Pohl U, Krotz F: Suppression of DNAPKcs enhances FGF-2 dependent human endothelial cell proliferation via negative regulation of Akt. Cell Signal 2010, 22:88-96.

27. Ades EW, Candal FJ, Swerlick RA, George VG, Summers S, Bosse DC, Lawley TJ: HMEC-1: establishment of an immortalized human microvascular endothelial cell line. J Invest Dermatol 1992, 99:683-690.

28. Krotz F, de Wit C, Sohn HY, Zahler S, Gloe T, Pohl U, Plank C: Magnetofection-a highly efficient tool for antisense oligonucleotide delivery in vitro and in vivo. Mol Ther 2003, 7:700-710.

29. Wornle M, Schmid H, Banas B, Merkle M, Henger A, Roeder M, Blattner S, Bock E, Kretzler M, Grone HJ, Schlondorff D: Novel role of toll-like receptor 3 in hepatitis C-associated glomerulonephritis. Am J Pathol 2006, 168:370-385.

30. Mannell HK, Pircher J, Chaudhry DI, Alig SK, Koch EG, Mettler R, Pohl U, Krotz F: ARNO regulates VEGF-dependent tissue responses by stabilizing endothelial VEGFR-2 surface expression. Cardiovasc Res 2012, 93:111-119.

31. Massberg S, Enders G, Leiderer R, Eisenmenger S, Vestweber D, Krombach F, Messmer K: Platelet-endothelial cell interactions during ischemia/ reperfusion: the role of P-selectin. Blood 1998, 92:507-515.

32. Ferrero E, Zocchi MR, Magni E, Panzeri MC, Curnis F, Rugarli C, Ferrero ME, Corti A: Roles of tumor necrosis factor p55 and p75 receptors in TNFalpha-induced vascular permeability. Am J Physiol Cell Physiol 2001, 281: C1173-1179.

33. Pignatelli P, De Biase L, Lenti L, Tocci G, Brunelli A, Cangemi R, Riondino S, Grego S, Volpe M, Violi F: Tumor necrosis factor-alpha as trigger of platelet activation in patients with heart failure. Blood 2005, 106:1992-1994.

34. Piguet PF, Vesin C, Da Kan C: Activation of platelet caspases by TNF and its consequences for kinetics. Cytokine 2002, 18:222-230.

35. Cambien B, Bergmeier W, Saffaripour S, Mitchell HA, Wagner DD: Antithrombotic activity of TNF-alpha. J Clin Invest 2003, 112:1589-1596. 
36. Yoshida H, Yilmaz CE, Granger DN: Role of tumor necrosis factor-alpha in the extraintestinal thrombosis associated with colonic inflammation. Inflamm Bowel Dis 2011, 17:2217-2223.

37. Kollias G, Kontoyiannis D: Role of TNF/TNFR in autoimmunity: specific TNF receptor blockade may be advantageous to anti-TNF treatments. Cytokine Growth Factor Rev 2002, 13:315-321.

38. Wajant $\mathrm{H}$, Pfizenmaier $\mathrm{K}$, Scheurich P: Tumor necrosis factor signaling. Cell Death Differ 2003, 10:45-65.

39. Branen L, Hovgaard L, Nitulescu M, Bengtsson E, Nilsson J, Jovinge S: Inhibition of tumor necrosis factor-alpha reduces atherosclerosis in apolipoprotein E knockout mice. Arterioscler Thromb Vasc Biol 2004, 24:2137-2142

40. Chandrasekharan UM, Mavrakis L, Bonfield TL, Smith JD, DiCorleto PE: Decreased atherosclerosis in mice deficient in tumor necrosis factoralpha receptor-II (p75). Arterioscler Thromb Vasc Biol 2007, 27:e16-17.

41. Blessing E, Bea F, Kuo CC, Campbell LA, Chesebro B, Rosenfeld ME: Lesion progression and plaque composition are not altered in older apoE ${ }^{-/}$ mice lacking tumor necrosis factor-alpha receptor p55. Atherosclerosis 2004, 176:227-232.

42. Chandrasekharan UM, Siemionow M, Unsal M, Yang L, Poptic E, Bohn J, Ozer K, Zhou Z, Howe PH, Penn M, DiCorleto PE: Tumor necrosis factor alpha (TNF-alpha) receptor-II is required for TNF-alpha-induced leukocyte-endothelial interaction in vivo. Blood 2007, 109:1938-1944.

43. Davies R, Galloway JB, Watson KD, Lunt M, Symmons DP, Hyrich KL: Venous thrombotic events are not increased in patients with rheumatoid arthritis treated with anti-TNF therapy: results from the British Society for Rheumatology Biologics Register. Ann Rheum Dis 2011, 70:1831-1834.

doi:10.1186/ar4064

Cite this article as: Pircher et al:: Prothrombotic effects of tumor necrosis factor alpha in vivo are amplified by the absence of TNF-alpha receptor subtype 1 and require TNF-alpha receptor subtype 2. Arthritis

Research \& Therapy 2012 14:R225.

\section{Submit your next manuscript to BioMed Central and take full advantage of:}

- Convenient online submission

- Thorough peer review

- No space constraints or color figure charges

- Immediate publication on acceptance

- Inclusion in PubMed, CAS, Scopus and Google Scholar

- Research which is freely available for redistribution

Submit your manuscript at www.biomedcentral.com/submit 